\title{
A study on Evaluating and managing the financial risks of local banks in Henan Province based on Analytic Hierarchy Process Model
}

\author{
Xiaona $\mathrm{Li}^{1}$,Ruoqian Yang,Junyuan Zhao \\ Department of Economic Management, XinYang Normal University Huarui College, \\ HeNan Xinyang 464000,China \\ yangruoqian88618@163.com
}

Keywords: local banks; financial risks; Analytic Hierarchy Process

\begin{abstract}
Henan is a populous province in China, and its banking system is sound. The development of local banks plays an significant role in economic development of Henan Province. For these factors, some suggestions are presented, such as increasing capital accumulation rate reasonably, improving the management of credit risk, realizing the diversification of profits and controlling cost-income ratio effectively.
\end{abstract}

\section{Background}

Economic globalization promoted the rapid development of Finance since 1990s.A variety of (Various) financial products were introduced in 2013, and government significantly introduced various financial reform policies[1][2]. On February 28, 2015, the central bank announced that the deposit and loan interest rates would decreased by $0.25 \%$ form March 1st 2015, and China's financial reform process continued to accelerate. Every economic agents' need for financial system was enhanced under the market economic system, and local banks having crisis would cause a certain impact on China's economy[3][4]. Evaluating the financial risks of local banks, finding out the important factors which influenced them in Henan Province could be effectively control the financial risks[5].

\section{Introduction of analytic hierarchy process}

Analytic hierarchy process which combined qualitative analysis and quantitative analysis was proposed by T.L.Saaty, a professor from University of Pittsburgh, US in 1970s.

\subsection{Establish the hierarchy model}

The level is divided into three classes of top, middle and bottom. There is only one element in top, several elements in middle, and various measures in bottom.

\subsection{Construct judgment matrix}

Represent their level of importance in the form of the ratio of the two comparative importance degrees, and construct judgment matrix. When comparing the importance of the two factors, 1, 3, 5, 7, 9 are used to express its quantitative value, 1 means that the two factors are equally important, 3 indicates that the first factor is slightly important, 5 means that the first factor is more important, 7 indicates that the first factor is very important, 9 means that the first factor is absolutely important In addition, with 2, 4, 6, 8 to represent the importance between the above two adjacent levels.

\subsection{Calculated the relative weight of each element}

Normalized processing of the judgment matrix, the maximum eigenvalue of judgment matrix $\_-\lambda \max$ and the relative weight of each element are calculated.

\footnotetext{
${ }^{1}$ About the author: Xiaona Li(1983-), female, the Han nationality, research direction: investment project analysis and management.
} 


\subsection{For coincidence test}

Using CI to measure the deviation of the matrix, and $C I=\frac{\lambda_{\max }-n}{n-1}$, the smaller the value, the closer the judgment matrix to the complete agreement; Using RI to express the average random consistency, as is shown in Table 1 ; $\mathrm{CR}=\mathrm{CI} / \mathrm{RI}$, when $\mathrm{CR}<0.1(<0.1 \mathrm{CR})$, it has a satisfactory consistency.

Table.1 Mean random consistency index RI standard value table

\begin{tabular}{|c|c|c|c|c|c|c|c|c|c|c|}
\hline Matrix order: $\mathrm{n}$ & 1 & 2 & 3 & 4 & 5 & 6 & 7 & 8 & 9 & 10 \\
\hline RI & 0 & 0 & 0.58 & 0.9 & 1.12 & 1.24 & 1.32 & 1.41 & 1.45 & 1.49 \\
\hline
\end{tabular}

\subsection{Calculated the combination weight of each element}

According to the relative weight of each element in each layer from top to bottom, the combination weight of all the elements in the bottom layer was calculated.

\section{Evaluate the financial risks of local banks in Henan Province}

\subsection{Introduction of Henan local Banks}

Henan is a larger province in China, and its banking system is sound. The local banks in Henan Province are mainly composed of 17 city commercial Banks, 207 small and new rural financial institutions. 13 city commercial banks, including Xinyang bank, Kaifeng bank, Xinxiang bank and Xuchang bank formed a regional joint-stock commercial bank, which was the central bank. The development of local banks plays an significant role in economic development of Henan Province.

\subsection{Evaluate the financial risks of local banks in Henan Province}

The financial risks of local banks in Henan Province would be divided into three levels, which are the top, middle and bottom. The top level $\mathrm{X}$ is measured by financial risk. Reference to notice

《Risk rating system of the joint-stock commercial banks (Provisional)》, which was issued by the China banking regulatory commission, the middle level is consist of capital adequacy $\mathrm{X}_{1}$, credit risk $\mathrm{X}_{2}$, operational risk $\mathrm{X}_{3}$, liquidity risk $\mathrm{X}_{4}$, development capacity risk $\mathrm{X}_{5}$.

Each of the middle level $\mathrm{X}$ has its underlying index. Capital adequacy index $\mathrm{X}_{1}$ mainly include (includes)capital adequacy ratio $\mathrm{X}_{11}$, core capital adequacy ratio $\mathrm{X}_{12}$ and asset liability ratio $\mathrm{X}_{13}$; credit risk $\mathrm{X}_{2}$ mainly include non-performing loan ratio $\mathrm{X}_{21}$ more than 90 days overdue loan ratio $\mathrm{X}_{22}$, the largest single customer loan proportion $\mathrm{X}_{23}$, loan ratio of the ten largest customers $\mathrm{X}_{24}$ and provision coverage ratio $\mathrm{X}_{25}$; operational risk $\mathrm{X}_{3}$ mainly include asset profit margin $\mathrm{X}_{31}$, capital profit margin $\mathrm{X}_{32}$, cost income ratio $\mathrm{X}_{33}$ and non-interest income ratio $\mathrm{X}_{34}$; liquidity risk $\mathrm{X}_{4}$ mainly include current ratio $\mathrm{X}_{41}$, deposit and loan rates $\mathrm{X}_{42}$, RMB excess reserve ratio $\mathrm{X}_{43}$ and net lending capital ratios $\mathrm{X}_{44}$; development capacity risk $\mathrm{X}_{5}$ mainly include net profit growth rate $\mathrm{X}_{51}$, capital accumulation rate $\mathrm{X}_{52}$ and operating income growth rate $\mathrm{X}_{53}$.

\subsection{Evaluate the financial risks of local banks in Henan Province}

\section{Construct judgment matrix.}

In this paper, 50 experts were consulted, and 47 valid questionnaires were available. According to the experience of the experts, the judgment matrix of middle layer is shown in Table 2:

Table. 2 Two judgment matrix

\begin{tabular}{c|c|c|c|c|c}
\hline $\mathrm{X}$ & $\mathrm{X}_{1}$ & $\mathrm{X}_{2}$ & $\mathrm{X}_{3}$ & $\mathrm{X}_{4}$ & $\mathrm{X}_{5}$ \\
\hline
\end{tabular}




\begin{tabular}{c|c|c|c|c|c}
\hline $\mathrm{X}_{1}$ & 1 & $1 / 3$ & $1 / 2$ & $1 / 2$ & $1 / 3$ \\
$\mathrm{X}_{2}$ & 3 & 1 & 2 & 2 & 1 \\
$\mathrm{X}_{3}$ & 2 & $1 / 2$ & 1 & 1 & $1 / 2$ \\
$\mathrm{X}_{4}$ & 2 & $1 / 2$ & 1 & 1 & $1 / 2$ \\
$\mathrm{X}_{5}$ & 3 & 1 & 2 & 2 & 1 \\
\hline
\end{tabular}

\section{Calculate the weight.}

Normalized the column vectors of judgment matrix in table 2, according to the row sum, sum with the row order, then normalized processing, the relative importance weight of every index to financial risks could be get, and the weight is $\mathrm{W}=\left(\begin{array}{lllll}0.088 & 0.298 & 0.158 & 0.158 & 0.298\end{array}\right)$.

\section{Calculate the combination weight of each element}

The same for other matrices to calculate, $\mathrm{W}_{1}=\left(\begin{array}{lll}0.297 & 0.539 & 0.164\end{array}\right) ; \mathrm{W}_{2}=\left(\begin{array}{lll}0.446 & 0.286\end{array}\right.$ $\left.\begin{array}{lll}0.151 & 0.078 & 0.039\end{array}\right) ; \mathrm{W}_{3}=\left(\begin{array}{llll}0.081 & 0.155 & 0.476 & 0.288\end{array}\right) ; \mathrm{W}_{4}=\left(\begin{array}{llll}0.476 & 0.081 & 0.288\end{array}\right.$ $0.155) ; \mathrm{W}_{5}=\left(\begin{array}{lll}0.277 & 0.595 & 0.128\end{array}\right)$, and the consistency test is passed respectively.

The combination weight of each element is calculated, as shown in Table 3:

Table. 3 Comprehensive evaluation weight value

\begin{tabular}{|c|c|c|}
\hline The weight of middle layer & The weight of bottom layer & $\begin{array}{c}\text { The combination } \\
\text { weight }\end{array}$ \\
\hline \multirow{3}{*}{ capital adequacy $\mathrm{X}_{1}=0.088$} & capital adequacy ratio $X_{11}=0.297$ & 0.026 \\
\hline & $\begin{array}{c}\text { core capital adequacy ratio } \\
\mathrm{X}_{12}=0.539\end{array}$ & 0.047 \\
\hline & asset liability ratio $X_{13}=0.164$ & 0.014 \\
\hline \multirow{5}{*}{ credit risk $\mathrm{X}_{2}=0.298$} & $\begin{array}{c}\text { non-performing loan ratio } \\
\mathrm{X}_{21}=0.446 \\
\end{array}$ & 0.133 \\
\hline & $\begin{array}{l}\text { more than } 90 \text { days overdue loan } \\
\text { ratio } X_{22}=0.286\end{array}$ & 0.085 \\
\hline & $\begin{array}{l}\text { the largest single customer loan } \\
\text { proportion } \mathrm{X}_{23}=0.151\end{array}$ & 0.045 \\
\hline & $\begin{array}{c}\text { loan ratio of the ten largest } \\
\text { customers } \mathrm{X}_{24}=0.078\end{array}$ & 0.023 \\
\hline & $\begin{array}{c}\text { provision coverage ratio } \\
\mathrm{X}_{25}=0.039\end{array}$ & 0.012 \\
\hline \multirow{4}{*}{ operational risk $X_{3}=0.158$} & asset profit margin $X_{31}=0.081$ & 0.013 \\
\hline & capital profit margin $X_{32}=0.155$ & 0.024 \\
\hline & cost income ratio $X_{33}=0.476$ & 0.075 \\
\hline & $\begin{array}{c}\text { non-interest income ratio } \\
\mathrm{X}_{34}=0.288 \\
\end{array}$ & 0.046 \\
\hline \multirow{4}{*}{ liquidity risk $X_{4}=0.158$} & current ratio $\mathrm{X}_{41}=0.476$ & 0.075 \\
\hline & deposit and loan rate $X_{42}=0.081$ & 0.013 \\
\hline & $\begin{array}{c}\text { RMB excess reserve ratio } \\
\mathrm{X}_{43}=0.288\end{array}$ & 0.046 \\
\hline & net lending capital ratio $X_{44}=0.155$ & 0.024 \\
\hline \multirow{3}{*}{$\begin{array}{l}\text { development capacity risk } \\
\qquad \mathrm{X}_{5}=0.298\end{array}$} & net profit growth rate $\mathrm{X}_{51}=0.277$ & 0.083 \\
\hline & $\begin{array}{c}\text { capital accumulation rate } \\
\mathrm{X}_{52}=0.595\end{array}$ & 0.177 \\
\hline & operating income growth rate & 0.039 \\
\hline
\end{tabular}




\section{$\mathrm{X}_{53}=0.128$}

\subsection{Risk assessment results of local banks in Henan Province}

From the above risk assessment process, the most influential factor affecting local banks in Henan Province is capital accumulation rate, and the first five influencing factors are capital accumulation rate, non-performing loan ratio, more than 90 days overdue loan ratio, net profit growth rate and cost income ratio.

\section{Countermeasures and suggestions for financial risks prevention of local banks in Henan Province}

\subsection{Reasonably increase capital accumulation rate}

Capital accumulation rate refers to the ratio of the growth of the owner's equity to the amount of the owner's equity at the beginning of the year. Increasing capital accumulation rate reasonably can improve the ability of local banks to accumulate their capital, provide funds for their reserve development, and provide assistance for their further development.

\subsection{Improve credit risk management}

In this process of credit business, risk management is essential. In order to improve the internal control of credit risk in local banks, firstly the risk awareness of customer manager should be strengthened, and the possible non-performing loans should be controlled.

\subsection{Achieve diversification of profit}

Market environment changes quickly, so under the background of internet banking accelerated development, basing on their own endowment, local banks in Henan Province should actively promote the innovation of the internet banking business, increase non interest income, transform their operating structure, improve the operating characteristics, to achieve diversification of profit, and to win a more stable development.

\subsection{Effectively control cost income ratio}

Cost income ratio is necessary for local banks in Henan Province to do business, but high cost income ratio would cause waste of resources, so the ratio could be effectively controlled. And in order to control the ratio, firstly costs should be controlled, and the cost quota should be reduced. In addition, the operating efficiency could be improved.

\section{Acknowledgment}

This work is supported by key scientific research projects of Henan Province" research on the development of local banks in Central Plains Economic Zone" in 2015 (15B630016); Supported by XinYang Normal University Huarui College "research on Cross-regional operating earnings and risk of City commercial Banks in Henan Province "in 2015 (2015yb30), all support is gratefully acknowledged.

\section{References}

[1] Beijing Morning Post: Central bank issued a notice: deposit and loan interest rate fell by 0.25 percent. [EB/OL].(2015-03-01) [2015-05-03].

[2] Li Fangyan. Research on risk assessment of commercial banks in China [D].Hefei: Anhui University, 2014.

[3] Li Guomin, Zheng Yuxiao. The influence of interest rate marketization of henan local Banks[J].The financial theory and practice,2015.3.

[4] Jing xin, Wang Huacheng. Financial management [M].Beijing: China Renmin University Press, 2012.

[5] Cui hong. Uncover the fog of cost-income ratio in banks [J]. Securities Market Weekly,2010,5. 